\title{
KEKUATAN KARAKTER SANTRI
}

\author{
Fuad Nashori \\ Universitas Islam Indonesia \\ Email: fuadnashori@yahoo.com
}

\section{Abstract}

This paper mainly discusses 24 character strengths of students who learn in some Islamic Boarding Schools, particularly their strengths and weaknesses. The object of research was students staying at boarding house and actively studying in some universities of Yogyakarta. Total of respondents was 100 students of 62 males and 38 females. The data analysis was conducted through Value in Action-Inventory Strength method (VIA-IS). The result shows that five strong characters possessed by students were gratitude, kindness, citizenship, fairness and hope. On the other hand, their weakest ones were self regulation, bravery, creativity, perspective and sense of humor.

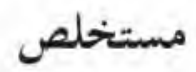

تبحث هنه البورقة أساسا القوبة الحرف 24 من الطلاب الذين يتعلمبون في المعهد الإسلامية، لا سيما نقاط قوقمم وضعفهم. وكان الهدف من البحوبث الطلاب البقاء المتزل المعهل ، ودراسة بنشاط في بعض الجامعات من يوجياكارتا. وكان بحموع المشاركين 100 طالب وطالبة من 62 من الذكور والإناث 38. وقد أجري تحليل البيانات

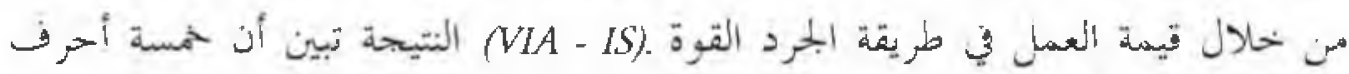

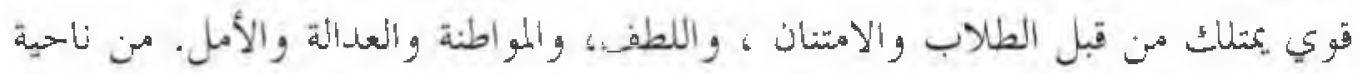

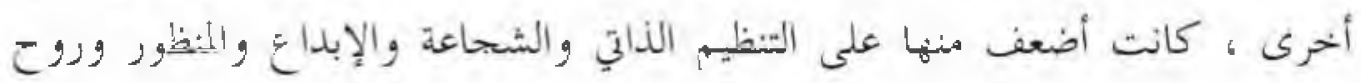
المدعابة.

Keywords: Santri, Kekuatan Karakter, Pondok Pesantren 


\section{A. Pendahuluan}

Dalam beberapa tahun terakhir ini, santri menjadi sorotan. Salah satu sorotan yang menonjol adalah keterlibatan santri dalam terorisme. Sejumlah nama yang berlatar belakang pendidikan pondok pesantren terlibat dalam berbagai aksi peledakan bom di Indonesia. Menanggapi fenomena ini, ingin penulis sampaikan bahwa ada kecenderungan pada berbagai pihak, baik di Indonesia maupun masyarakat internasional, untuk melakukan overgeneralisasi terhadap keterlibatan santri dalam terorisme ${ }^{1}$. Overgeneralisasi yang dimaksud adalah kecenderungan untuk menganggap bahwa semua -atau sekurang-kurangnya sebagian besar- santri memiliki kecenderungan untuk mengambil jalan pintas dalam menjalankan peran mencegah kemungkaran (nahi munkar). Overgeneralisasi ini memperkuat stereotipe santri sebagai teroris.

Dalam realitasnya, santri memiliki sejumlah karakteristik psikologis yang sama sebagaimana halnya non-santri, bahkan dalam beberapa hal lebih baik daripada non-santri. Penelitian yang dilakukan Fuad Nashori ${ }^{2}$ menunjukkan bahwa kelapangdadaan mahasiswa-santri dan mahasiswa-reguler secara statistik tidak berbeda. Kelapangdadaan sendiri dapat diartikan seabagai kondisi psiko-spiritual yang ditandai oleh kemampuan menerima berbagai kenyataan yang tidak menyenangkan dengan tenang dan terkendali. Artinya, santri dan non-santri tidak berbeda dalam kemampuannya menerima kenyataan yang tidak menyenangkan.

Dalam beberapa hal santri menunjukkan karakteristik psikologis yang lebih menonjol dibanding dengan non-santri. Hal ini sebagaimana dapat dilihat dari penelitian Mohamad Soleh ${ }^{3}$ yang menunjukkan bahwa kebermaknaan hidup mahasiswa santri lebih tinggi dibanding mahasiswa reguler. Mahasiswa santri menunjukkan kehidupan yang penuh gairah dan optimis, hidupnya terarah dan bertujuan, mampu beradaptasi, luwes dalam bergaul dengan tetap menjaga identitas diri. Bila dihadapkan pada permasalahan, orang yang memiliki kebermaknaan hidup -dalam hal ini mahasiswa santri-lebih tabah dan menyadari adanya hikmah di balik penderitaan.

1 H. Fuad Nashori, Psikologi Santri (editorial). Jumnal Psikologi Islami 1 (2), (2005), hal. 105.

2 H. Fuad Nashori, "Kelapangdadaan Mahasiswa-Santri dan Mahasiswa-Reguler. Jurnal Psikologi Islami” (2005), 1 (2), hal. 137.

3 Mohammad Soleh, "Kebermaknaan Hidup Mahasiswa Reguler dan Mahasiswa Unggulan (Santri) Universitas Islam Indonesia”, Jurnal Psikologika 6, (2001), hal. 59. 
Selain kebermaknaan hidup, santri juga menonjol dalam hal konsep diri. Penelitian Irvan Usman dan Fuad Nashori ${ }^{4}$ menunjukkan santri memiliki konsep diri yang lebih tinggi dibanding dengan siswa sekolah menengah umum. Santri memiliki konsep diri fisik, pribadi, sosial, keluarga, moral, dan akademik yang lebih tinggi dibanding siswa sekolah menengah umum.

Berbagai penelitian psikologi menunjukkan bahwa santri memiliki karakteristik yang positif, seperti sikap yang positif terhadap perilaku pro-lingkungan hidup ${ }^{5}$, kepuasaan hidupnya sedang ${ }^{6}$, dan kontrol dirinya sedang ${ }^{7}$. Berkaitan dengan sikap terhadap lingkungan hidup, para santri memiliki nilai-nilai Islami yang prolingkungan hidup seperti tidak memetik bunga atau buah yang belum saatnya dipetik. Budaya pesantren yang kolektivistik dan menekankan pentingnya konformitas menjadikan santri bersikap positif terhadap lingkungan hidup. ${ }^{8}$

Penelitian yang berjenis korelasional menunjukkan bahwa santri yang intensif melakukan dzikir memiliki agresivitas yang rendah' ${ }^{9}$ Dengan berdzikir akan tercipta suasana yang rileks saat dzikir maupun di luar dzikir. Suasana yang tenang ini dapat menghentikan gambaran-gambaran dalam pikiran yang menyebabkan terjadinya kemarahan. Penelitian lainnya menunjukkan bahwa santri (lansia) yang intensif berdzikir memiliki kontrol diri yang baik ${ }^{10}$. Dzikir mampu meningkatkan konsentrasi, semangat hidup, dan keseimbangan emosional. Selain itu, penelitian yang dilakukan Ahmad Muhammad Diponegoro ${ }^{11}$ menemukan bahwa santri yang memiliki afek positif akan memiliki kepuasan hidup yang tinggi. Afek yang tinggi diperoleh dari pengamalan ajaran Islam.

Dari penjelasan-penjelasan di atas, muncul pertanyaan bagaimana sesungguhnya karakter santri? Untuk mendapatkan gambaran tentang karakter mereka, maka salah

4 Irvan Usman \& H. Fuad Nashori, "Konsep Diri Santri Pondok Pesantren dan Siswa Sekolah Menengah Umum”, Jurnal Psikoislamika 5 (2), (2008), hal. 194.

5 Fattah Hanurawan, "Sikap Santri Pondok Pesantren Laki-laki dan Perempuan terhadap Perilaku Pro-Lingkungan Hidup”. Jurnal Psikologi Islami 1 (2), (2005), 127.

6 Ahmad Muhammad Diponegoro, "Afek dan Kepuasan Hidup Santri”, Jurnal Psikologi Islami 1 (2), (2005), hal. 107-118.

7 Rahmat Aziz \& Yuliati Hotifah, "Dzikir dan Kontrol Diri Santri Manula". Jurnal Psikologi Islami 1 (2), (2005), hal. 153-162.

8 Fattah Hanurawan, "Sikap Santri Pondok...”, hal . 125-126.

9 Baidi Bukhori, “Intensitas Dzikir dan Agresivitas pada Santri”. Jurnal Psikologi Islami 1 (2), (2005), hal. 148.

10 Rahmat Aziz \& Yuliati Hotifah, “Dzikir dan Kontrol Diri...”, hal. 160.

11 Ahmad Muhammad Diponegoro, “Afek dan Kepuasan Hidup Santri...”, hal. 113. 
satu upaya yang dapat dilakukan adalah berupaya memperoleh gambaran yang komprehensif tentang kondisi santri. Salah satu pendekatan yang dapat digunakan untuk memahami karakter santri dengan menggunakan teori kekuatan karakter yang dibangun dan dikembangkan oleh Peterson dan Seligman ${ }^{12}$. Kekuatan karakter (character strength), sebagaimana diungkapkan Park, Peterson, dan Seligman merupakan karakter baik yang mengarahkan individu pada pencapaian keutamaan atau trait positif yang terefleksi dalam pikiran, perasaan dan tingkah laku ${ }^{13}$.

Istilah kekuatan karakter (character strength) sering bersandingan dengan istilah keutamaan (virtue). Dalam konteks ini kekuatan karakter merupakan bagian dari keutamaan. Keutamaan (virtue) ialah karakter-karakter inti yang dipandang penting oleh agamawan dan para filsuf moral. Sementara kekuatan karakter (character strength) merupakan komponen-komponen psikologis, khususnya yang berkaitan dengan proses dan mekanisme, yang memperjelas keutamaan ${ }^{14}$. Peterson dan Seligman membagi karakter-karakter positif manusia menjadi 24 kekuatan karakter yang berada di bawah naungan 6 keutamaan (virtue), yakni:

1. Virtue 1: Wisdom and Knowledge terdiri atas 5 karakter, yaitu Creativity, Curiosity, Open-mindedness, Love of learning, Perspective.

2. Virtue 2: Courage terdiri atas 4 karakter, yaitu Bravery, Persistence, Integrity, Vitality.

3. Virtue 3: Humanity terdiri atas 3 karakter yaitu Love, Kindness, Social Intelligence.

4. Virtue 4: Justice terdiri atas 3 karakter, yaitu Citizenship, Fairness, Leadership.

5. Virtue 5: Temperance terdiri atas 4 karakter, yaitu Forgiveness and Mercy, Humility/Modesty, Prudence, Self-regulation.

6. Virtue 6: Transcendence terdiri atas Appreciation of beauty and excellence, Gratitude, Hope, Humor, Spirituality.

Struktur keutamaan (virtue) dan kekuatan karakter (character strength) dapat dilihat dari gambar di bawah ini:

12 Christopher Peterson \& Martin E.P. Seligman, M.E.P., Character Strengths and Virtues. (Oxford: Oxford University Press, 2004), hal. 4.

13 Nansook Park, Christopher Peterson \& Martin E.P. Seligman, Strengths of character and well-being. Journal of Social and Clinical Psychology 23, (2004), hal. 609.

14 Christopher Peterson \& Martin E.P. Seligman, M.E.P., Character Strengths and Virtues...., hal. 29. 


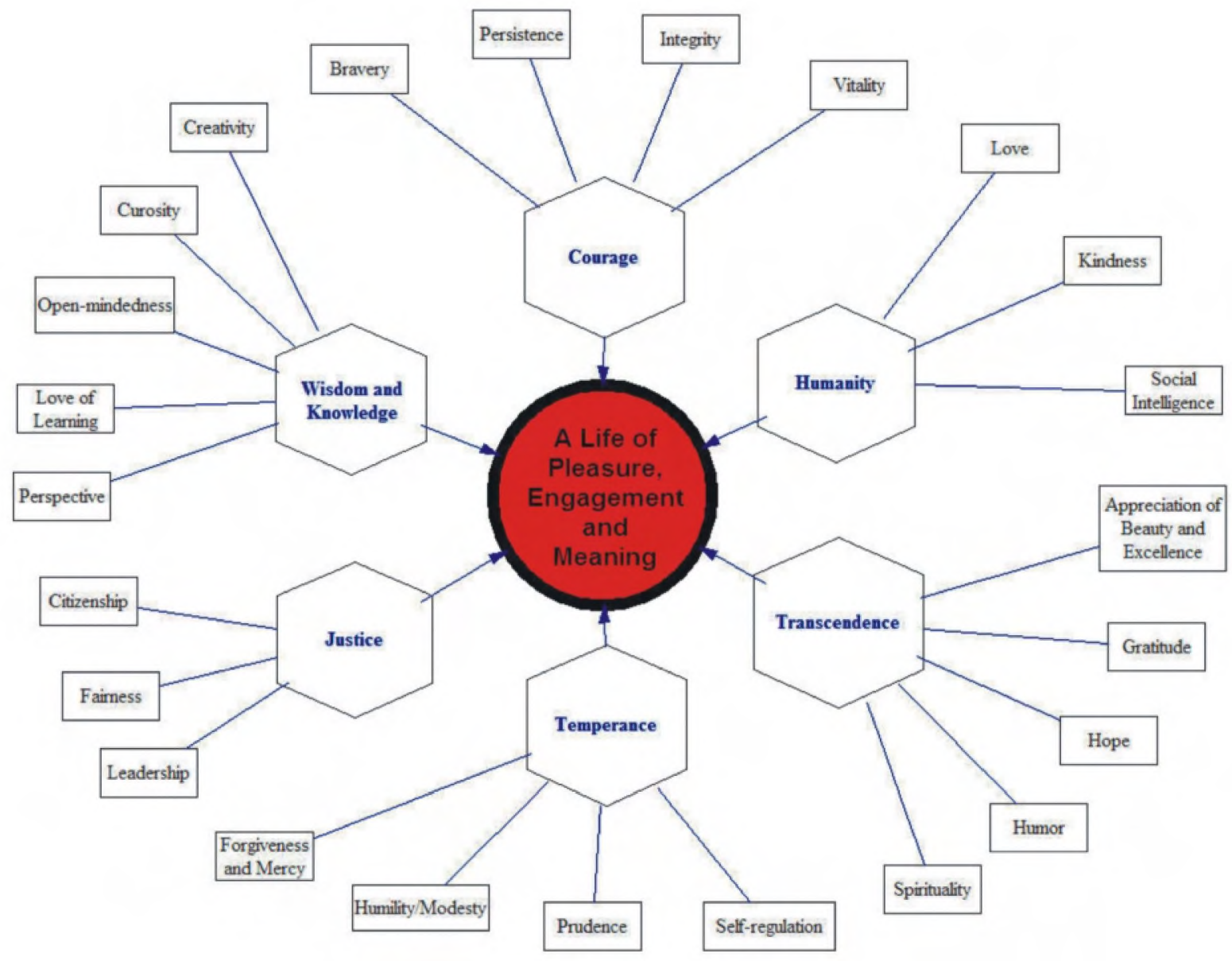

Gambar 1.

\section{Virtue 24 of Character Strengths (Peterson \& Seligman, 2004)}

Peterson dan Seligman ${ }^{15}$ mengatakan bahwa kekuatan karakter dan keutamaan dipengaruhi budaya dapat terlihat pada hasil-hasil penelitian yang telah dilakukan. Park, Peterson, dan Seligman ${ }^{16}$ menemukan dari penelitiannya bahwa kekuatan karakter yang menonjol di Amerika adalah kebaikan hati (kindness), keterusterangan (honesty), kebersyukuran (gratitude), dan penalaran (judgement). Bagaimana dengan kekuatan karakter bangsa Indonesia dan khususnya santri?

15 Christopher Peterson \& Martin E.P. Seligman, M.E.P., Character Strengths and Virtues... hal 37.

${ }^{16}$ Nansook Park, Christoper Peterson \& Martin E.P. Seligman. Character strengths in fiftyfour..., hal. 125. 
Fivi Nurwianti dan Imelda Dian Oriza dalam penelitiannya terhadap enam suku bangsa Indonesia menemukan bahwa karakter yang paling menonjol di Indonesia adalah kebersyukuran (gratitude), kebaikaan hati (kindness), kewargaan (citizenship), keadilan (fairness), dan kejujuran (integrity) ${ }^{17}$. Di sisi lain, karakter yang paling lemah pada bangsa Indonesia, khususnya suku Jawa, Sunda, Minangkabau, Batak, Betawi, dan Bugis adalah kreativitas atau creativity (mampu berkarya secara produktif, mampu berpikir unik), keberanian atau bravery (tidak takut terhadap ancaman, tantangan, kesulitan, atau rasa sakit, berani mengutarakan keinginan walaupun ada lawan, dan berani tampil berbeda walaupun tidak populer), regulasi diri atau self regulation (kedisiplinan dan kemampuan mengontrol emosi dan selera), cinta belajar atau love of learning (menguasai topik-topik ilmu pengetahuan baik formal maupun non formal, menguasai berbagai ketrampilan baru), dan keragaman sudut pandang atau perspective (memiliki cara pandang yang luas dan dapat diterima oleh orang lain, mampu memberi saran, dan bijaksana). ${ }^{18}$

Kaum santri, yang merupakan bagian integral dari bangsa Indonesia, diduga memiliki karakter yang mirip dengan karakter bangsa Indonesia pada umumnya. Hal ini didasarkan pada pandangan bahwa santri tumbuh, berkembang, dan hidup dalam bingkai budaya bangsa Indonesia. Dengan demikian, dapat diajukan pertanyaan: benarkah santri memiliki karakter menonjol dan karakter yang lemah sama dengan yang sama dengan karakter bangsa Indonesia bangsa Indonesia?

\section{B. Metode Penelitian}

\section{Responden Penelitian}

Penelitian ini dilakukan pada santri yang tinggal di pondok pesantren dan sedang menempuh pendidikan tinggi di Yogyakarta. Jumlah responden penelitian adalah 100 orang yang terdiri atas 7 santri Pondok Pesantren Wakhid Hasyim, 22 santri Pondok Pesantren Darush Shalihat, 30 santri Pondok Pesantren Sunan Pandanaran, dan 41 santri Pondok Pesantren UII. Mereka terbagi dalam jenis

17 Fivi Nurwianti \& Imelda Dian Oriza, Explorative Study of Character Strength on Indonesian Poeple, Book of Abstracts, The First International Conference of Indigenous and Cultural Psychology, Yogyakarta, 24-27 July 2010, hal. 36.

18 Imelda Dian Oriza \& Fivi Nurwianti, Hubungan antara Kekuatan karakter dan Kebahagiaan pada Orang Indonesia, Ringkasan Laporan Penelitian (Depok: Fakultas Psikologi UI, 2010), hal. 11. 
kelamin lelaki sebanyak 62 orang dan berjenis kelamin perempuan 38 orang. Responden umumnya berasal dari etnis Jawa 69 orang, tak beridentitas 8 , Sunda 7 , Minang 2, Lampung 2, Aceh 1, Melayu 1, Betawi 1, Banjar 1, Madura 1, Sumbawa 1, Bima 1, Bugis 1, Jawa-Sunda 1, Jawa-Betawi 1, Jawa-Jambi 1, dan Jawa-Madura 1. Sampel untuk penelitian ini akan diambil dengan menggunakan metode nonprobability sampling. Dalam metode ini tidak semua anggota populasi memiliki kesempatan yang sama untuk menjadi sampel dalam penelitian ${ }^{19}$. Teknik sampling yang digunakan pada penelitian ini adalah purposive sampling, yaitu menggunakan karakterisitik tertentu pada responden penelitian yang memiliki informasi yang dibutuhkan dan bersedia untuk memberikan informasi tersebut kepada peneliti ${ }^{20}$.

\section{Alat Ukur Penelitian}

Alat ukur yang digunakan untuk pengambilan data adalah Value in Action Inventory Strength (VIA-IS). Alat ukur ini terdiri dari item-item untuk mengukur 24 kekuatan karakter, yaitu forgiveness, humility, prudence, self regulation, appreciation of beauty, gratitude, hope, humor, dan spirituality, creativity, curiosity, open-mindedness, love of learning, perspective, bravery, persistence, integrity, vitality, love, kindness, social intelligence, citizenships, fairness, dan leadership,.

Versi asli VIA-IS terdiri atas 240 item yang dimaksudkan untuk mengukur 24 kekuatan karakter. Masing-masing karakter diukur dengan 10 item. Pada versi adaptasi yang digunakan dalam penelitian ini, item berjumlah 172 buah $^{21}$. Alat ini menggunakan skala Likert dengan 6 pilihan jawaban.

Perhitungan reliabilitas dan validitas dilakukan untuk masing-masing kekuatan karakter. Koefisien reliabilitas untuk masing-masing kekuatan karakter berkisar antara 0.603 - 0.844 . Koefisien alpha untuk alat ukur kekuatan karakter secara keseluruhan sebesar 0.978. Metode pengujian validitas dengan kriteria konsistensi internal lainnya adalah dengan mengkorelasikan total skor di setiap dimensi dengan total skor keseluruhan. Hasil dari korelasi tersebut didapat hasil koefisien korelasi antara masing-masing kekuatan dengan skor total kekuatan karakter bervariasi mulai dari $.861-.532$ (signifikan pada L.o.S .01 ( $\mathrm{p}<.001)$ ).

19 Fred N. Kerlinger \& Howard B. Lee, Foundations of behavioral research ( $4^{\text {th }}$ ed) (USA, Wadsworth, 2000), hal. 78.

20 Ranjit Kumar, Research methodology, a step-by-step guide for beginners (London: Sage Publications, 1999), hal. 125.

${ }^{21}$ Imelda Dian Oriza \& Fivi Nurwianti, Hubungan antara Kekuatan Karakter dan Kebahagiaan pada Orang Indonesia... hal. 11. 


\section{Hasil Penelitian}

Analisis deskriptif karakter santri dimaksudkan untuk mengetahui karakter santri yang paling menonjol hingga karakter santri yang paling lemah. Berikut ini adalah urutan karakter dari 100 responden penelitian.

Tabel 1. Karakter yang Paling Menonjol Hingga yang Paling Lemah pada Santri Yogyakarta

\begin{tabular}{|c|c|c|c|c|c|c|}
\hline No & Character & $\mathbf{N}$ & Min & $\operatorname{Max}$ & Mean & $\begin{array}{l}\text { Standard } \\
\text { Deviation }\end{array}$ \\
\hline 1 & Gratitude & 100 & 3.670 & 6.000 & 5.26670 & .533629 \\
\hline 2 & Fairness & 100 & 3.500 & 11.0000 & 5.019840 & .761981 \\
\hline 3 & Citizenship & 100 & 3.570 & 6.000 & 5.08980 & .500210 \\
\hline 4 & Kindriess & 100 & 3.440 & 6.000 & 5.08920 & .499134 \\
\hline 5 & Hope & 100 & 3.250 & 6.000 & 5.00760 & .541164 \\
\hline 6 & Spirituality & 100 & 3.38 & 6.00 & 4.7672 & .61483 \\
\hline 7 & Inteyrity & 95 & 3.570 & 6.000 & 4.93947 & .469593 \\
\hline 8 & Leaderstip & 100 & 3.400 & 6.000 & 4.95000 & .561653 \\
\hline 9 & Open Mindedness & 100 & 3.330 & 6.000 & 4.90040 & .501075 \\
\hline 10 & Forgiveness & 100 & 3.250 & 6.000 & 4.89380 & .576220 \\
\hline 11 & Love & 100 & 3.140 & 0.000 & 4.78130 & .059212 \\
\hline 12 & Persistance & 100 & 2.570 & 6.000 & 4.77030 & .627902 \\
\hline 13 & Curnousity & 100 & 3.375 & 6.000 & 4.76500 & .615273 \\
\hline 14 & Pruterce & 100 & 3.14 & 5.86 & 4.7629 & .61202 \\
\hline 15 & Vulality & 100 & 2.880 & 5.880 & 4.74640 & .618338 \\
\hline 16 & Humility & 100 & 2.750 & 6.000 & 4.73750 & .575571 \\
\hline 17 & Social Intelligence & 100 & 3.000 & 6.000 & 4.72660 & .608439 \\
\hline 18 & Love of Learnjing & 100 & 2.860 & 5.860 & 4.72370 & .641869 \\
\hline 19 & Appreciation of Beaty & 100 & 3.22 & 6.00 & 4.7143 & .61568 \\
\hline 20 & Humor & 100 & 3.250 & 6.000 & 4.71040 & .601500 \\
\hline 2$]$ & Perspective & 100 & 3.000 & 6.000 & 4.70100 & .551965 \\
\hline 22 & Creativity & 100 & 2.750 & 6.000 & 4.68250 & .621434 \\
\hline 23 & Bravery & 100 & 2.500 & 5.830 & 4.46290 & .662477 \\
\hline 24 & Self Regulation & 100 & 2.500 & 6.000 & 4.20750 & .714262 \\
\hline
\end{tabular}


Dari tabel di atas dapat diketahui bahwa lima karakter yang paling menonjol pada diri santri adalah kebersyukuran (gratitude), keadilan (fairness), kewargaan (citizenship), kebaikaan hati (kindness), dan harapan (hope). Tabel 1 juga menunjukkan karakter yang paling lemah pada diri santri adalah regulasi diri (self regulation), keberanian (bravery), kreativitas (creativity), keragaman sudut pandang (perspective), dan humor.

\section{Pembahasan}

\section{Hasil Utama Penelitian}

Hasil utama penelitian menunjukkan bahwa karakter yang paling menonjol pada santri Yogyakarta adalah kebersyukuran (gratitude), keadilan (fairness), kewargaan (citizenship), kebaikan hati (kindness), dan harapan (hope).

Hasil penelitian ini tidak jauh berbeda dengan hasil penelitian Fivi Nurwianti dan Imelda Dian Oriza tentang karakter bangsa Indonesia. Lima karakter paling menonjol dan berurutan pada bangsa Indonesia, khususnya enam suku (Jawa, Sunda, Minangkabau, Batak, Betawi, dan Bugis), adalah kebersyukuran (gratitude), kebaikaan hati (kindness), kewargaan (citizenship), keadilan (fairness), dan kejujuran (integrity) Secara khusus hasil penelitian ini juga searah dengan hasil penelitian Nurwianti dan Oriza tentang karakter suku bangsa Jawa, suku bangsa mayoritas subjek penelitian. Lima karakter yang paling menonjol secara berurutan pada etnis Jawa adalah gratitude, kindness, citizenship, fairness, dan integrity.

Dengan demikian, dapat diketahui bahwa kesamaan karakter antara santri dan enam suku bangsa Indonesia adalah empat karakter utama, yaitu kebersyukuran, kebaikan hati, kewargaan, dan keadilan. Perbedaan yang paling nyata adalah munculnya karakter harapan dalam jajaran lima karakter santri yang paling menonjol, padahal pada enam suku karakter kelima yang menonjol adalah kejujuran.

Hasil penelitian ini mendukung pandangan beberapa ahli sebelumnya. Dikatakan oleh M. Dawam Rahardjo bahwa secara umum santri mempelajari banyak ragam pengetahuan yang berkaitan dengan nilai-nilai agama yang bersifat positif bagi kehidupannya, baik dalam hubungan dengan Sang Pencipta, sesama manusia, maupun dengan alam lingkungan ${ }^{23}$. Ahmad Muhammad Diponegoro

22 Fivi Nurwianti \& Imelda Dian Oriza, Explorative Study of Character Strength on Indonesian Poeple, Book of Abstracts, The First International Conference of Indigenous and Cultural Psychology, Yogyakarta, 24-27 July 2010, hal. 36.

23 Fattah Hanurawan, "Sikap Santri Pondok Pesantren Laki-laki dan Perempuan terhadap Perilaku Pro-Lingkungan Hidup...”, hal. 121. 
mengungkapkan bahwa selama di Pondok Pesantren para santri cenderung mengadopsi nilai-nilai Islam seperti persaudaraan (ukhuwah), persatuan (ittihad), tolong menolong (ta'awun), dan kepatuhan (tha'at) kepada Tuhan, Rasul, Ulama/ Kyai, dan orang-orang yang diakui sebagai pemimpin. Persaudaraan, persatuan, dan tolong menolong adalah nilai-nilai yang membentuk dan memperkuat karakter kebersyukuran (gratitude), kebaikan hati (kindness) dan kewargaan (citizenship). Rasa syukur ada dalam hati, ucapan, dan perbuatan. Perbuatan yang dimaksud adalah memberi pertolongan kepada orang lain.

Sementara itu M. Dawam Rahardjo mengungkapkan bahwa nilai-nilai yang banyak dipelajari di pondok pesantren adalah sikap adil, hemat dan tidak berlebihan, serta suka menolong sesama ${ }^{24}$. Bila pandangan ini dikaitkan dengan hasil penelitian, maka dapat diungkapkan nilai sikap adil akan menguatkan karakter keadilan (fairness), nilai hemat dan tidak berlebihan akan menguatkan karakter keberyukuran (gratitude), dan nilai suka menolong sesama akan menguatkan karakter kebersyukuran (gratitude), kebaikan hati (kindness) dan kewargaan (citizenship).

2. Kebersyukuran (gratitude) Santri

Dari analisis data penelitian diketahui bahwa karakter yang paling menonjol pada diri santri adalah kebersyukuran (gratitude). Sebagaimana diketahui, kebersyukuran adalah karakter penting yang dihidupkan oleh masyarakat, dan khususnya, lingkungan pondok pesantren. Kebersyukuran (gratitude) terdiri atas (a) sadar dan bersyukur atas anugerah Tuhan dan (b) menyediakan waktu untuk mengekspresikan rasa bersyukur.

Kebersyukuran sendiri diajarkan dan dihidupkan dalam kehidupannyata santri. Dalam Islam, kebersyukuran termasuk sesuatu yang sangat prinsip. Umat Islam diajarkan untuk bersyukur kepada Tuhan, baik dalam hati, secara lisan, maupun dalam perilaku. Salah satu contoh ayat suci al-Qur'an yang memerintahkan kebersyukuran adalah janji Allah 'azza wa jalla untuk menambah rizki bila seseorang bersyukur dan sebaliknya akan melaknat manusia bila seseorang mengingkarinya ${ }^{25}$. Di sini jelas ditekankan pentingnya kesadaran bahwa rizki yang dimiliki manusia bersumber dari Allah 'azza wa jalla.

Lebih dari itu, kebersyukuran kepada Tuhan itu selayaknya diekspresikan dalam bentuk kebaikan, kemurahan hati dan pertolongan kepada orang lain. Syukur tidak

24 Fattah Hanurawan, ibid.

25 Al-Qur'an Surat Ibrahim (14) ayat 7 . 
hanya kesadaran dalam hati dan ucapan, tapi yang paling penting adalah dalam bentuk perbuatan.

Dalam kehidupan riil, rasa syukur santri diekspresikan dalam bentuk kemudahan memberikan apa yang dimilikinya kepada santri-santri yang lain. Bila memperolah rizki dalam bentuk makanan misalnya, maka mereka mudah membaginya kepada teman-temannya.

\section{Keadilan (fairness) Santri}

Temuan penting yang lain berkaitan dengan karakter santri adalah keadilan. Dibanding dengan karakter keadilan pada bangsa Indonesia umumnya, santri memiliki karakter keadilan yang lebih menonjol. Indikator keadilan adalah memperlakukan setiap orang secara adil, memberikan kesempatan yang sama pada setiap orang, dan tidak membiarkan perasaan subjektif mempengaruhi keputusan yang menyangkut orang lain.

Keadilan sendiri merupakan ajaran penting yang diajarkan dalam pondok pesantren ${ }^{26}$. Penekanan pentingnya keadilan dalam pesantren bersumber dari dalam ajaran Islam. Dalam al-Qur'an, manusia diperintahkan berbuat adil terhadap diri sendiri, ibu dan bapak, kaum kerabat ${ }^{27}$, dan kepada seluruh umat manusia. ${ }^{28}$.

Karakter keadilan dalam diri santri memperoleh persemaiannya dalam kehidupan sehari-hari dalam pondok pesantren. Di pesantren terdapat peraturan-peraturan yang harus ditegakkan bersama-sama. Mereka sadar bahwa kalau melakukan kesalahan, maka mereka harus menerima hukuman atas kesalahannya itu. Lingkungan pondok pesantren yang secara relatif banyak menegakkan peraturan pada semua warga pesantren berimplikasi pada kuatnya karakter keadilan pada diri santri.

\section{Kebaikan Hati (kindness) dan Kewargaan (citizenship) Santri}

Temuan menonjol lainnya adalah kebaikan hati (kindness) dan kewargaan (citizenship). Indikator kebaikan hati adalah (a) melakukan kebaikan kepada orang lain, menolong orang lain, menjaga orang lain, dan mengerti perasaan orang lain. Sementara itu indikator kewargaan adalah bekerja dengan baik pada situasi kelompok dan setia kepada kelompok.

${ }^{26}$ Fattah Hanurawan, "Sikap Santri Pondok Pesantren Laki-laki dan Perempuan terhadap Perilaku Pro-Lingkungan Hidup...”, hal. 121.

27 Al-Qur'an Surat An-Nisa' (4) ayat 135.

28 Al-Qur'an Surat An-Nisa' (4) ayat 58. 
Di pondok pesantren, santri tidak hanya mendapat pelajaran tentang kebaikan hati dan kewargaan, tetapi juga mempraktikkannya. Sebagaimana diketahui, di pondok pesantren, santri hidup dalam suasana kolektivistik ${ }^{29}$. Kalau mereka memiliki sesuatu, dalam hal ini adalah makanan atau yang lain, maka mereka akan mudah membaginya kepada yang lain. Apabila ada santri yang berada dalam kesulitan, teman-temannya dengan sangat muah memberikan pertolongan. Hal ini sejalan dengan pandangan Diponegoro yang mengungkapkan bahwa salah satu ajaran Islam yang banyak diadopsi pondok pesantren adalah persaudaraan (ukhuwah), persatuan (ittihad), tolong menolong (ta'awun) ${ }^{30}$.

Pentingnya kebaikan hati dan kewargaan ini dengan jelas ditekankan dalam agama Islam. Perintah untuk tolong menolong bisa dilihat dalam berbagai ayat suci. Salah satu ayat suci al-Qur'an memerintahkan agar manusia saling menolong dalam kebaikan dan takwa serta tidak tolong menolong dalam kesesatan dan dosa ${ }^{31}$. Dalam suatu hadis Nabi Muhammad juga ditunjukkan sesama mukmin saling mencintai, mengasihi, dan bersikap baik satu sama layaknya sebuah tubuh. Apabila salah satu bagian tubuh sakit, maka bagian yang lain merasakan sakit juga ${ }^{32}$.

\section{Harapan (hope) Santri}

Karakter kelima yang menonjol pada diri santri adalah harapan. Indikator-indikator dari karakter harapan adalah (a) mengharapkan yang terbaik untuk masa depan dan berusaha untuk mewujudkannya, (b) yakin dan percaya bahwa nasib bisa berubah dan masa depan yang baik bisa dicapai, dan (c) memiliki pandangan yang positif.

Harapan yang kuat dalam diri santri bersumber dari ajaran Islam yang menekankan pentingnya keyakinan masa depan yang lebih baik. Dalam al-Qur'an digambarkan bahwa sesudah kesulitan ada kemudahan ${ }^{33}$.

Kuatnya karakter harapan (hope) pada santri ini berkaitan dengan usia dan pendidikan mereka. Responden penelitian ini umumnya adalah orang yang berusia dewasa awal, yang menurut Elizabeth B. Hurlock dimulai sejak 18 tahun $^{34}$. Saat ini

${ }^{29}$ Ahmad M. Diponegoro, “Afek dan Kepuasan Hidup Santri...”, hal. 109.

30 Ibid.

31 Al-Qur'an Surat AL-Maidah (5) ayat 2.

${ }^{32}$ Imam Zabidi (penyusun), Ringkasan Shahih Bukhari, (Penerbit Mizan, Bandung, 2002), hal. 849.

33 Al-Qur'an Surat An-Nisa' (4) ayat 58.

${ }^{34}$ Elizabeth B. Hurlock, A Life Span Approach. $5^{\text {th }}$ ed. (New York: McGraw-Hill, Inc, 1980), hal. 98. 
mereka membekali diri mereka dengan ilmu pengetahuan yang mereka dalami di perguruan tinggi. Kemudaan usia ditambah dengan bekal yang telah mereka terima menjadikan mereka memiliki harapan yang tinggi untuk kehidupan pribadi mereka maupun kehidupan bersama.

\section{Regulasi Diri Santri}

Penelitian ini menunjukkan bahwa santri memiliki karakter yang paling lemah dalam bentuk regulasi diri yang tidak optimal. Di satu sisi mereka memiliki harapan (hope), namun ternyata mereka tidak memiliki kemampuan regulasi diri. Indikatorindikator regulasi diri adalah (a) kedisiplinan dan (b) kemampuan mengontrol emosi dan selera.

Hasil penelitian ini searah dengan hasil temuan Imelda Dian Oriza dan Fivi Nurwianti yang menempatkan regulasi diri sebagai karakter yang lemah yang ketiga pada sejumlah suku bangsa Indonesia. ${ }^{35}$

Dugaan yang dapat diberikan adalah usia dan pendidikan yang ditempuh santri. Subjek penelitian ini adalah santri yang sedang menempuh pendidikan tinggi. Berbeda dengan siswa menengah umum yang penuh kedisiplinan, pada saat mahasiswa seseorang memiliki kedisiplinan yang relatif rendah. Pada usia mahasiswa ini seseorang memiliki kebebasan dalam mengekspresikan diri, termasuk emosi dan selera.

\section{Keberanian Santri}

Penelitian ini menunjukkan bahwa karakter santri yang cukup lemah atau tidak menonjol adalah keberanian. Indikator keberanian adalah (a) tidak takut terhadap ancaman, tantangan, kesulitan, atau rasa sakit, (b) berani mengutarakan keinginan walaupun ada lawan, dan (c) berani tampil berbeda walaupun tidak populer. Hasil penelitian ini searah dengan hasil temuan Imelda Dian Oriza dan Fivi Nurwianti yang menempatkan keberanian sebagai karakter yang lemah yang kedua pada sejumlah suku bangsa Indonesia ${ }^{36}$

Tidak berkembangnya keberanian pada diri santri karena budaya organisasi dalam pondok pesantren yang menekankan kepatuhan (tha'at). Alih-alih berani tampil berbeda walapaun tidak populer, mereka lebih suka memilih perilaku yang selaras. Hal ini terutama mengingat mereka tinggal dalam lingkungan yang kolektivistik.

35 Imelda Dian Oriza \& Fivi Nurwianti, Hubungan antara Kekuatan karakter dan Kebahagiaan pada Orang Indonesia....., hal. 11.

36 Ibid. 
Rendahnya karakter keberanian dalam diri santri ini sekaligus mengkonfirmasi adanya kesalahan overgeneralisasi ketika sejumlah santri terlibat dalam terorisme ${ }^{37}$. Overgeneralisasi bahwa santri adalah teroris adalah kesalahan berpikir dan kesalahan empiris. Mereka memiliki karakter kindness yang sangat menonjol dan keberanian yang lemah. Dengan karakter semacam ini, dapat dinyatakan dan diprediksikan bahwa santri tidak tepat disebut sebagai teroris.

\section{Kreativitas dan Kekayaan Sudut Pandang Santri}

Hasil penelitian ini menunjukkan bahwa santri memiliki kreativitas dan kekayaan sudut pandang (perspective) yang kurang menonjol. Hasil penelitian ini searah dengan hasil temuan Imelda Dian Oriza dan Fivi Nurwianti yang menempatkan kreativitas dan perspective sebagai karakter yang lemah pada sejumlah suku bangsa Indonesia ${ }^{38}$.

Kenyataan tentang lemahnya kreativitas ini jauh-jauh hari telah dikritisi oleh Utami Munandar. Ahli kreativitas ini mengungkapkan bahwa kreativitas akan tumbuh dan berkembang pada kebudayaan yang menghargai kreativitas. Yang menjadi masalah adalah ternyata umumnya guru -dan umumnya pendidik - tidak menempatkan nilai-nilai kreativitas dan nilai yang dekat dengan kreativitas (seperti inisiatif) sebagai sesuatu yang penting. Ciri-ciri murid yang diinginkan guru adalah sopan, rajin, sehat, dan patuh" ${ }^{39}$.

Kreativitas dilatari oleh kekayaan sudut pandang (perspective). Kemampuan untuk melihat sudut pandang yang beragam termasuk karakter yang paling lemah dibanding dengan 23 karakter lainnya. Karakter ini berkaitan dengan cara pandang yang luas dan dapat diterima oleh orang lain, mampu memberi saran, dan bijaksana. Di pondok pesantren, karakter ini tidak mendapat pelayanan secara optimal. Di pesantren, santri dibiasakan melihat segala sesuatu dengan sudut pandang normatif, dalam hal ini adalah norma-norma yang ada dalam agama Islam. Pergaulan mereka pun umumnya sangat intens dengan sesama penghuni pondok dan secara relatif kurang terbiasa bergaul dengan lingkungan sosial yang lebih bebas.

\section{Humor Santri}

Penelitian menunjukkan bahwa karakter yang paling tidak menonjol kelima santri adalah humor. Indikator karakter humor adalah (a) senang tertawa, bercanda, menghibur/ menggoda orang lain, (b) mempertahankan mood yang baik, dan (c)

37 H. Fuad Nashori, "Psikologi Santri (editorial)...", hal. 105.

38 Imelda Dian Oriza \& Fivi Nurwianti, "Hubungan antara Kekuatan...", hal. 11.

39 Fuad Nashori \& Rachmy Diana Mucharam, Mengembangkan Kreativitas dalam Perspektif Psikologi Islami, (Yogyakarta: Penerbit Menara Kudus, 2002), hal. 58-59. 
melihat segala sesuatu dari sisi yang positif. Hasil penelitian berbeda dengan hasil penelitian Imelda Dian Oriza dan Fivi Nurwianti yang tidak menempatkan humor sebagai lima karakter yang paling lemah ${ }^{40}$

Dugaan yang dapat diberikan adalah dalam Islam humor termasuk sesuatu yang harus dilakukan dengan sangat hati-hati. Dalam Islam misalkan diharapkan individu dapat tertawa secara wajar sehingga tidak patut orang tertawa dalam keadaan mulut terbuka. Karena adanya pembatasan-pembatasan itu, maka subjek tidak menjadikan humor sebagai karakteristik penting.

\section{E. Penutup}

\section{Simpulan}

Simpulan yang dapat diambil dari penelitian ini adalah di antara 24 karakter, terdapat 5 karakter yang paling menonjol pada diri santri adalah kebersyukuran (gratitude), keadilan (fairness), kebaikaan hati (kindness), kewargaan (citizenship), dan harapan (hope). Hasil penelitian ini tak jauh berbeda dengan penelitian sebelumnya. Penelitian sebelumnya menemukan bahwa 5 karakter yang paling menonjol pada bangsa Indonesia adalah kebersyukuran (gratitude), kebaikaan hati (kindness), kewargaan (citizenship), keadilan (fairness), dan kejujuran (integrity). Dibanding dengan karakter bangsa Indonesia umumnya, karakter harapan (hope) santri lebih menonjol.

Di sisi lain, karakter yang paling lemah pada santri adalah regulasi diri (self regulation), keberanian (bravery), kreativitas (creativity), keragaman sudut pandang (perspective), dan humor. Hasil penelitian ini tidak jauh berbeda dengan penelitian sebelumnya. Penelitian sebelumnya menemukan bahwa karakter yang paling lemah adalah kreativitas (creativity), keberanian (bravery), regulasi diri (self regulation), cinta belajar (love of learning), keragaman sudut pandang (perspective). Dibanding dengan karakter bangsa Indonesia umumnya, karakter humor santri lebih lemah.

\section{Rekomendasi}

Peneliti-peneliti setelah ini direkomendasikan untuk melihat keterkaitan antara karakter dengan berbagai fenomena psiko-sosial yang saat ini berkembang, seperti agresivitas, terorisme, korupsi, kebahagiaan, kesehatan mental, dan sejenisnya. Direkomendasikan pula agar penelitian-penelitian selanjutnya menggunakan metode penelitian yang lebih bervariasi, seperti korelasi, komparasi, dan eksperimen.

${ }^{40}$ Imelda Dian Oriza \& Fivi Nurwianti, "Hubungan antara Kekuatan...", hal. 11. 


\section{DAFTAR PUSTAKA}

Aziz, Rahmat. \& Hotifah, Yuliati. 2005. Dzikir dan Kontrol Diri Santri Manula. Jurnal Psikologi Islami. Yogyakarta: PP Asosiasi Psikologi Islami.

Bukhori, Baidi. 2005. Intensitas Dzikir dan Agresivitas pada Santri. Jurnal Psikologi Islami. Yogyakarta: PP Asosiasi Psikologi Islami.

Diponegoro, Ahmad.M. 2005. Afek dan Kepuasan Hidup Santri. Jurnal Psikologi Islami. Yogyakarta: PP Asosiasi Psikologi Islami.

Hanurawan, Fattah. 2005. Sikap Santri Pondok Pesantren Laki-laki dan Perempuan terhadap Perilaku Pro-Lingkungan Hidup. Jurnal Psikologi Islami. Yogyakarta: PP Asosiasi Psikologi Islami.

Hurlock, Elizabeth.B. 1980. Developmental Psychology: A Life Span Approach. $5^{\text {th }}$ ed. New York: McGraw-Hill, Inc.

Kerlinger, Fred N., \& Lee, Howard B. 2000. Foundations of Behavioral Research ( $4^{\text {th }}$ ed). USA: Wadsworth.

Kumar, Ranjit. 1999. Research Methodology, a Step-by-step Guide for Beginners. London: Sage Publications.

Nashori, H.Fuad. \& Rachmy Diana Mucharam.2002. Mengembangkan Kreativitas dalam Perspektif Psikologi Islami. Yogyakarta: Penerbit Menara Kudus.

Nashori, H.Fuad. 2005. Psikologi Santri (editorial). Jurnal Psikologi Islami. Yogyakarta: PP Asosiasi Psikologi Islami.

Nashori, H.Fuad. 2005. Kelapangdadaan Mahasiswa-Santri dan Mahasiswa-Reguler. Jurnal Psikologi Islami. Yogyakarta: PP Asosiasi Psikologi Islami.

Nuqul, Fathul L. 2008. Pesantren Sebagai Bengkel Moral: Optimalisasi Sumber Daya Pesantren untuk Menanggulangi Kenakalan Remaja, Jurnal Psikoislamika. Malang: Fakultas Psikologi UIN Malang.

Nurwianti, Fivi \& Oriza, Imelda D. 2010. Explorative Study of Character Strength on Indonesian Poeple, Book of Abstracts, The First International Conference of Indigenous and Cultural Psychology, Yogyakarta (Gadjah Mada University), 24-27 July 2010. 
Oriza, Imelda.D. \& Nurwianti, Fivi. 2010. Hubungan antara Kekuatan karakter dan Kebahagiaan pada Orang Indonesia, Ringkasan Laporan Penelitian. Depok: Fakultas Psikologi UI.

Park, Nansook, Peterson, Christopher, \& Seligman, Martin E.P. 2004. Strengths of character and well-being. Journal of Social and Clinical Psychology. New York: Guilford.

Park, Nansook, Peterson, Christopher, \& Seligman, Martin EP. (2006). Character strengths in fifty-four nations and the fifty US states. The Journal of Positive Psychology. New York: Routledge, Taylor and Francis Group.

Peterson, C. \& Seligman, M.E.P. 2004. Character Strengths and Virtues. Oxford: Oxford University Press

Soleh, Mohammad. 2001. Kebermaknaan Hidup Mahasiswa Reguler dan mahasiswa unggulan universitas Islam Indonesia. Jurnal Psikologika. Yogyakarta: Fakultas Psikologi UII.

Tim Penerjemah. 2002. Al-Qur'an dan Terjemahannya. Jakarta: Departemen Agama RI.

Usman, Irvan \& Nashori, H.Fuad. 2008. Konsep diri santri pondok pesantren dan siswa sekolah menengah umum. Jurnal Psikoislamika. Malang: Fakultas Psikologi UIN Malang.

Zabidi, Imam (penyusun). 2002. Ringkasan Shahih Bukhari. Bandung: Penerbit Mizan. 